\title{
Stability and performance evaluation of the speed control of DC motor using state-feedback controller
}

\author{
Saad A. Salman', Zeyad Assi Obaid ${ }^{2}$, Haider Salim Hameed ${ }^{3}$ \\ ${ }^{1}$ Department of Computer Engineering, College of Engineering, University of Diyala, Iraq \\ ${ }^{2,3}$ Department of Electric Power and Machines Engineering, College of Engineering, University of Diyala, Iraq
}

\begin{tabular}{|c|c|}
\hline Article Info & ABSTRACT \\
\hline Article history: & Direct current (DC) motor are widely used in many applications due to its \\
\hline Received Mar 13, 2021 & $\begin{array}{l}\text { accurate control of speed and position. However, a proper control and } \\
\text { operation is still required and might be a challenge for control designers. This }\end{array}$ \\
\hline Revised May 2, 2021 & paper presents the design of a state-feedback control to evaluate the \\
\hline Accepted May 5, 2021 & $\begin{array}{l}\text { performance of the speed control of DC motor for different applications. The } \\
\text { simulation results were carried out with and without disturbance applied to }\end{array}$ \\
\hline Keywords: & $\begin{array}{l}\text { the system. The proposed control method showed a stable system response } \\
\text { with both cases of disturbances. Therefore, it can be used to solidate the } \\
\text { control of DC motor in the real application. }\end{array}$ \\
\hline
\end{tabular}

Stability analysis

State feedback controller

This is an open access article under the CC BY-SA license.

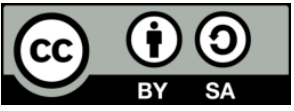

\section{Corresponding Author:}

Saad A. Salman

Department of Computer Engineering, College of Engineering,

University of Diyala

Baqubah, Diyala, Iraq

Email: drsaad_eng@uodiyala.edu.iq

\section{INTRODUCTION}

Direct current (DC) motor a device which was designed to convert electrical power to mechanical power. Excited DC motor is one type of DC motors which was widely used to illustrate the dynamic performance of a typical DC motor behaviour. The DC motor can be controlled by common two methods: i) by changing the applied voltage to the armature or ii) changing the applied voltage to the field winding [1]-[3]. Industrial DC motors were applied to many applications like electric vehicles, cranes, steel rolling mills and robotic due to many advantages such as, simple, precise, and characteristics of continuous control [4]-[7].

The development of the motor drives is very demandable in different industrial applications such as steel rolling mills, electric trains and robotics [8], [9]. In addition, these drive systems must have an acceptable tracking for the dynamic speed command and load control response to perform different tasks. DC motor drives, thanks to their simplicity, easist application, high standard of reliabilities, more flexibilities and reasonable cost have long been integrated and involved in many industrial applications such as robot manipulators and domestic appliances with the target of speed and position control. DC motors are superior in control of speed for deceleration and acceleration. DC motors are preferable for most horsepower ratings due to their reasonable cost. Moreover, DC motors have had been widely uses as speed machines due to its adjustable mechanism. In such applications, the motor should be controlled using a good control algorithm to provide the desired response performance [10]-[13]. 
The design and implementation of the state feedback controller using Matlab/simulink for position control of DC motor was presented in [14]. This system was designed using dSPACE DS1104 board as well as real DC motor. The experimental results in testing the Maxon DC motor showed the effectiveness of the control scheme and the motor position can be controlled over certain range.

In addition, the design of robust state feedback controller was approached in time domain for the uncertain DC-motor system was proposed by [15]. The goal was to observe their state vectors because the output vector of this real system was measurable. The controlled plant model was the 'polytopic' model of uncertain system. The linear matrix inequality (LMI) region was used to measure the stability performance of the closed loop system, where the poles of whole uncertainty domain are placed. The Lyapunov function was used to improve the the quadratic stability [15]. Design and implementation of various robust controllers for DC motor speed control with fixed field and different position values and constant speed was proposed in [16]. The method provides minimum rise time, overshoot, and fast settling time versus low steady state error. The closed-loop feedback control with different load characteristics were validated using both MATLAB and experimental representation.

In control theory, state variable analysis covers the initial conditions and time-variantlinvariant, linearInon-linear. Furthermore, single or multiple input output systems can also be analysed [17], [18]. The principle of feedback of all state variables feeding the input of the system was through a feedback matrix in the control strategy is preferable using full-state variable feedback control [19], [20]. State feedback is very useful for multi-input multi-output systems and for control systems with optimum constraints, such as those requiring a minimum time to final value or minimal control effort. The advantage of the state feedback method is that the controller parameters have a greater degree of freedom with respect to the output feedback method [21]-[24].

As explained above, DC motor has been used in too many applications due to simplicity of its mechanical structure to provide a superior response by controlling the position and speed. However, a proper control and operation is still an issue [14]. Therefore, the state feedback method was presented in this paper.

\section{MODEL OF DC MOTOR}

DC motors provide the cabability of high torque. However, this function is generally referring to the acual physical size of the motor. In addition, are easy to be minimized and can be "throttled" by adjusting their supplied voltage. These motors are the simplest and oldest electrical motors and most commonly used machines for electromechanical energy conversion. The major advantages of these kinds' motors are easy speed and torque regulation, Figure 1 shows the general layout of the DC motor model.

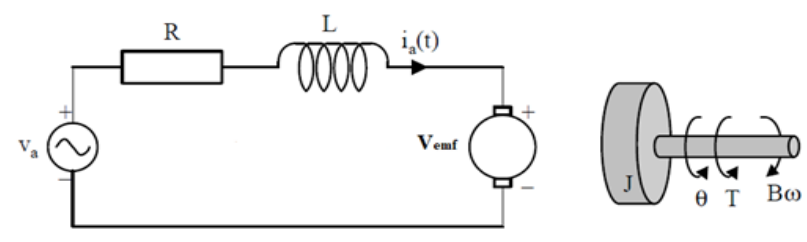

Figure 1. General layout of Model of DC motor

\subsection{Equation of the system}

The torque $(T)$ is referring to the armature current $\left(i_{a}\right)$ by using constant of the torque $\left(K_{T}\right)$,

$$
\mathrm{T}=\mathrm{K}_{\mathrm{T}} \mathrm{i}_{\mathrm{a}}
$$

the generated voltage is refered by $\left(\mathbf{V}_{\text {emf }}\right)$ and also is relating to the angular velocity $(\omega)$ by,

$$
\mathrm{V}_{\mathrm{emf}}=\mathrm{K}_{\omega} \omega=\mathrm{K}_{\omega} \frac{\mathrm{d} \theta}{\mathrm{dt}}
$$

by using Figure 1, and based on the Newton's law as well as the Kirchhoff's law the following equations can be writted,

$$
\begin{aligned}
& J \frac{d^{2} \theta}{d t^{2}}+B \frac{d \theta}{d t}=K_{T} i_{a} \\
& L \frac{d i_{a}}{d t}+R_{i}=V_{a}-K_{\omega} \frac{d \theta}{d t}
\end{aligned}
$$


using the Laplace transform, as shown in (3) and (4) can be written as,

$$
\begin{aligned}
& \mathrm{Js}^{2} \theta(\mathrm{s})+\mathrm{Bs} \theta(\mathrm{s})=\mathrm{K}_{\mathrm{T}} \mathrm{I}_{\mathrm{a}}(\mathrm{s}) \\
& \mathrm{L} \mathrm{sI}_{\mathrm{a}}(\mathrm{s})+\mathrm{RI}_{\mathrm{a}}(\mathrm{s})=\mathrm{V}_{\mathrm{a}}(\mathrm{s})-\mathrm{K}_{\omega} \mathrm{s} \theta(\mathrm{s})
\end{aligned}
$$

from shown in (6) we can express $I_{a}(s)$,

$$
I_{a}(s)=\frac{V_{a}(s)-K_{\omega} s \theta(s)}{R+L s}
$$

and substitute as shown in (7) in (5), we get,

$$
\mathrm{J} \mathrm{s}^{2} \theta(\mathrm{s})+\mathrm{Bs} \theta(\mathrm{s})=\mathrm{K}_{\mathrm{T}} \frac{\mathrm{V}_{\mathrm{a}}(\mathrm{s})-\mathrm{K}_{\omega} \mathrm{s} \theta(\mathrm{s})}{\mathrm{R}+\mathrm{Ls}}
$$

From shown in (8), the transfer function for angular velocity with respect to the input voltage $\mathrm{G}_{\mathrm{m}}(\mathrm{s})$ can be got,

$$
\mathrm{G}_{\mathrm{m}}(\mathrm{s})=\frac{\dot{\theta}(\mathrm{s})}{\mathrm{V}_{\mathrm{a}}(\mathrm{s})}=\frac{\mathrm{K}_{\mathrm{T}}}{(\mathrm{R}+\mathrm{Ls})(\mathrm{J}+\mathrm{B})+\mathrm{K}_{\mathrm{T}} \mathrm{K}_{\omega}}
$$

DC motor parameters are presented using Table 1 [25],

Table 1. Parameters of the presented Motor

\begin{tabular}{cl}
\hline $\mathrm{R}$ & \multicolumn{1}{c}{$4.67 \square$} \\
\hline $\mathrm{L}$ & $0.17 \mathrm{H}$ \\
$\mathrm{J}$ & $0.0426 e-3 \mathrm{Kg} . \mathrm{m} 2$ \\
$\mathrm{~B}$ & $0.0473 e-3 \mathrm{~N} . \mathrm{m}-\mathrm{rad} / \mathrm{sec}$ \\
$\mathrm{K}_{\mathrm{T}}$ & $0.0147 \mathrm{~N} . \mathrm{m} / \mathrm{A}$ \\
$\mathrm{K} \omega$ & $0.0147 \mathrm{~V} . \mathrm{sec} / \mathrm{rad}$ \\
\hline
\end{tabular}

The 'transfer function' $\mathrm{G}_{\mathrm{m}}$ for (DC) Motor, which represented the angular velocity with respect to input voltage is,

$$
G m(s)=\frac{2030}{s^{2}+28.58 s+60.34}
$$

\section{STATE_FEEDBACK_CONTROLLER DESIGN}

By Considering the state-space model of a (SISO system) shown in Figure 2 and (10).

$$
\begin{aligned}
& \mathrm{x}(\mathrm{k}+1)=\mathrm{Ax}(\mathrm{k})+\mathrm{Bu}(\mathrm{k}) \\
& \mathrm{y}(\mathrm{k})=\mathrm{Cx}(\mathrm{k})
\end{aligned}
$$

where $\left(\mathrm{x}(\mathrm{k}) \in \mathrm{R}^{\mathrm{n}}\right),(\mathrm{u}(\mathrm{k})$ and $\mathrm{y}(\mathrm{k}))$ are scalar. The states are located in feedback to the input location in order to have desired locations for the closed poles.

Affine State Feedback Law is,

$$
\mathrm{u}(\mathrm{k})=-\mathrm{Kx}(\mathrm{k})+\mathrm{v}(\mathrm{k})
$$

where $v(\mathrm{k})$ is the reference input and $\mathrm{K}$ (state feedback gain) is $\mathrm{R}^{1^{*} \mathrm{n}}$

If $v(\mathrm{k}) \neq 0$, the goal of the control design is the tracking, if $\mathbf{v}(\mathbf{k})=\mathbf{0}$, the design problem is known as regulation problem and state feedback law (control input) became,

$$
\mathrm{u}(\mathrm{k})=-\mathrm{K} \mathrm{x}(\mathrm{k})
$$

the state feedback control was also designed using pole placement control as shown in Figure 3. Substitute as shown in (12) in (10):

$$
\mathrm{x}(\mathrm{k}+1)=(\mathrm{A}-\mathrm{BK}) \mathrm{x}(\mathrm{k})
$$




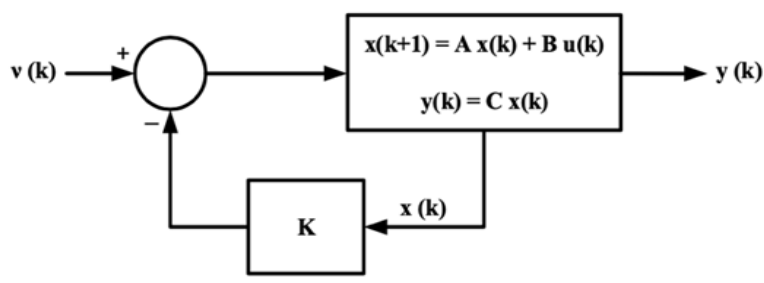

Figure 2. Closed_loop control system with 'state feedback control

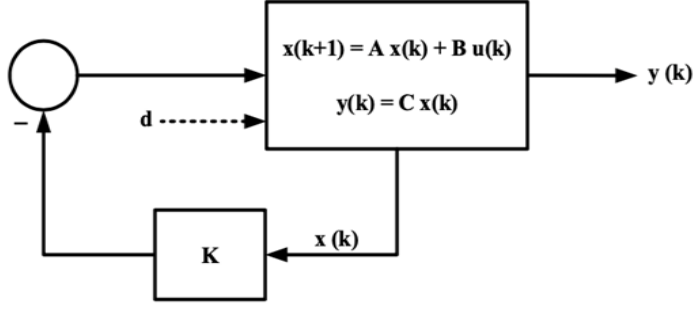

Figure 3. Closed loop control system with state feedback control and disturbance (input=0)

The problem of the regulation will be solved if $\mathrm{K}$ is designed with eigenvalues of $\mathrm{A}-\mathrm{BK}$ are located within the unit circle of the system. The closed loop poles of the system shown in (13) are place in desired locations by the control law, for this reason the state feedback gain matrix $\mathrm{K}$ is design. Therefore, the pair (A, B) must be controllable for accurate condition of arbitrary pole placement and all states are located in feedback to the input side (assume measurable). Transforming the state model into canonical form is shown in (14). The controllability matrix is written as $\mathrm{M}_{\mathrm{C}}$ and the transformation matrix is $\mathrm{T}$ :

$$
\mathrm{T}=\mathrm{MCH}
$$

where,

$$
\mathrm{H}=\left[\begin{array}{lllcc}
\mathrm{a}_{\mathrm{n}-1} & \mathrm{a}_{\mathrm{n}-2} & \cdots & \mathrm{a}_{1} & 1 \\
\mathrm{a}_{\mathrm{n}-2} & \mathrm{a}_{\mathrm{n}-3} & \cdots & 1 & 0 \\
\vdots & \vdots & \cdots & \vdots & \vdots \\
\mathrm{a}_{1} & 1 & \cdots & 0 & 0 \\
1 & 0 & \cdots & 0 & 0
\end{array}\right]
$$

ai are the characteristic coefficients $|z I-A|=z^{n}+a_{1} z^{n-1}+\cdots+a_{n-1} z+a_{n}$. The updated state vector $\mathbf{x}=\mathbf{T} \overline{\mathbf{x}}$ transforms the system (previously given by (10)) into controllable canonical form, as,

$$
\overline{\mathrm{x}}(\mathrm{k}+1)=\overline{\mathrm{A}} \overline{\mathrm{x}}(\mathrm{k})+\overline{\mathrm{B}} \mathrm{u}(\mathrm{k})
$$

where the following is verified,

and,

$$
\overline{\mathrm{A}}=\mathrm{T}^{-1} \mathrm{AT}=\left[\begin{array}{ccccc}
0 & 1 & 0 & \cdots & 0 \\
0 & 0 & 1 & \cdots & 0 \\
\vdots & \vdots & \vdots & \vdots & \vdots \\
0 & 0 & 0 & \cdots & 1 \\
-a_{n} & -a_{n-1} & -a_{n-2} & \cdots & -a_{1}
\end{array}\right]
$$

$$
\overline{\mathrm{B}}=\mathrm{T}^{-1} \mathrm{~B}=\left[\begin{array}{c}
\mathbf{0} \\
\mathbf{0} \\
\vdots \\
\mathbf{1}
\end{array}\right]
$$

Firstly, it is necessary to calculate $\overline{\mathrm{K}}$ so that $\mathrm{u}(\mathrm{k})=-\overline{\mathrm{K}} \overline{\mathrm{x}}(\mathrm{k})$ can place the poles in the desired locations. The eigenvalues will not be changed under similar transformation. In addition, $\mathrm{u}(\mathrm{k})=-\overline{\mathrm{K}} \mathrm{T}^{-1} \mathrm{x}(\mathrm{k})$ also places the poles in the desired locations. If poles are placed at $\mathrm{z}_{1}, \mathrm{z}_{2}, \ldots ., \mathrm{z}_{\mathrm{n}}$, the characteristic equation can be written as,

$$
\begin{aligned}
& (\mathrm{z}-\mathrm{z} 1)(\mathrm{z}-\mathrm{z} 2) \ldots(\mathrm{z}-\mathrm{zn})=0 \\
& \text { or, } \mathrm{zn}+\alpha 1 \mathrm{zn}-1+\ldots+\alpha \mathrm{n}-1 \mathrm{z}+\alpha \mathrm{n}=0
\end{aligned}
$$

the controllable $(\overline{\mathrm{A}}, \overline{\mathrm{B}})$ can be located in,

$$
\overline{\mathrm{A}}-\overline{\mathrm{B}} \overline{\mathrm{K}}=\left[\begin{array}{ccccc}
\mathbf{0} & \mathbf{1} & \mathbf{0} & \cdots & \mathbf{0} \\
\mathbf{0} & \mathbf{0} & \mathbf{1} & \cdots & \mathbf{0} \\
\vdots & \vdots & \vdots & \vdots & \vdots \\
\mathbf{0} & \mathbf{0} & \mathbf{0} & \cdots & \mathbf{1} \\
-\left(a_{n}-\overline{\mathbf{k}}_{1}\right) & -\left(a_{n-1}-\overline{\mathbf{k}}_{2}\right) & \cdots & -\left(a_{1}-\overline{\mathbf{k}}_{n}\right)
\end{array}\right]
$$


the original and canonical form has a characteristic equation as: $|z I-A|=|z I-\bar{A}|=z^{n}+a_{1} z^{n-1}+\ldots+a_{n}=0$ while the characteristic equation of thier closed loop with $\mathrm{u}=-\overline{\mathrm{K}} \overline{\mathrm{x}}$,

$$
\mathrm{zn}+\left(\mathrm{a} 1+\overline{\mathrm{k}}_{\mathrm{n}}\right) \mathrm{zn}-1+\left(\mathrm{a} 2+\overline{\mathrm{k}}_{\mathrm{n}-1}\right) \mathrm{zn}-2+. .+\left(\mathrm{an}+\overline{\mathrm{k}}_{1}\right)=0
$$

from comparing (16) and (17), results,

$$
\overline{\mathrm{k}}_{\mathrm{n}}=\alpha 1-\mathrm{a} 1, \overline{\mathrm{k}}_{\mathrm{n}-1}=\alpha 2-\mathrm{a} 2, \overline{\mathrm{k}}_{1}=\alpha \mathrm{n}-\mathrm{an}
$$

to find the actual gain matrix $\mathrm{K}=-\overline{\mathrm{K}} \mathrm{T}^{-1}$, should be compute the transformation matrix $\mathrm{T}$, where $\overline{\mathrm{K}}=\left[\overline{\mathrm{k}}_{1}\right.$, $\left.\overline{\mathrm{k}}_{2}, \ldots, \overline{\mathrm{k}}_{\mathrm{n}}\right]$.

\section{RESULTS AND DISCUSSIONS}

Firstlly, the transfer function of the DC motor $\mathrm{G}_{\mathrm{m}}(\mathrm{s})$ was transfed to state space representation (controllable canonical form), where the matrices of the state space. MATLAB/SIMULINK (R2015a) was used to finalize the simulation; it was used to demonstrate the robustness property of state feedback controller. Here, second order system is considered, which means that states of the system will reach the equilibrium in infinite time.

$$
\mathrm{A}=\left[\begin{array}{cc}
0 & 1 \\
-60.34 & -28.58
\end{array}\right] ; \mathrm{B}=\left[\begin{array}{l}
0 \\
1
\end{array}\right] ; \mathrm{C}=[20300] ; \mathrm{D}=[0]
$$

The initial state was applied into the system is $\mathrm{X}(0)=\left[\begin{array}{ll}1 & 0.5\end{array}\right]^{\mathrm{T}}$ and the estimated state feebback gain matrix $\mathrm{K}=\left[\begin{array}{ll}5.91 & 0.42\end{array}\right]$. First, the response for system without disturbance using state feedback controller is observed, both states will reach to the zero in infinite time as shown in Figures 4 and 5. In next step, a sinusoidal disturbance is introduced; it was shown that also both states will be reach to the zero in infinite time with very small oscillated as shown in Figures 6 and 7. State feedback control presented an acceptable response with stable behavior.

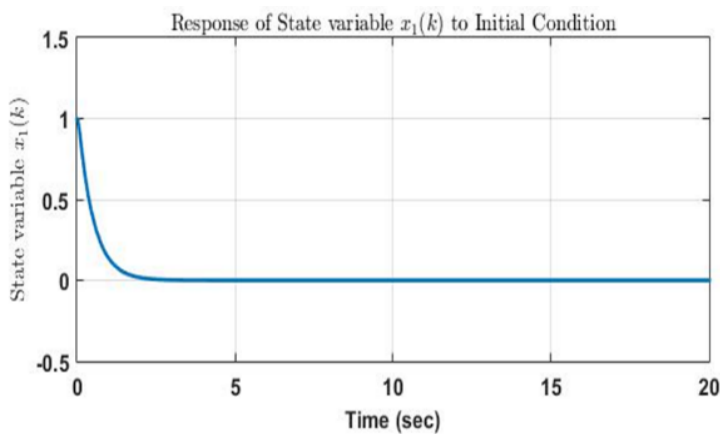

Figure 4. Showing state X1 without any disturbance

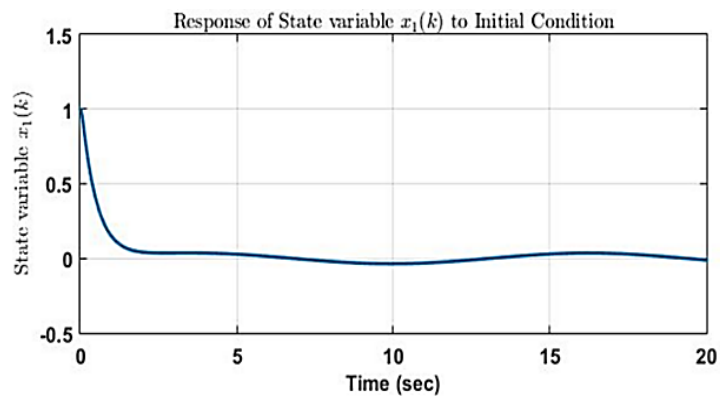

Figure 6. Showing state X1 with the disturbance

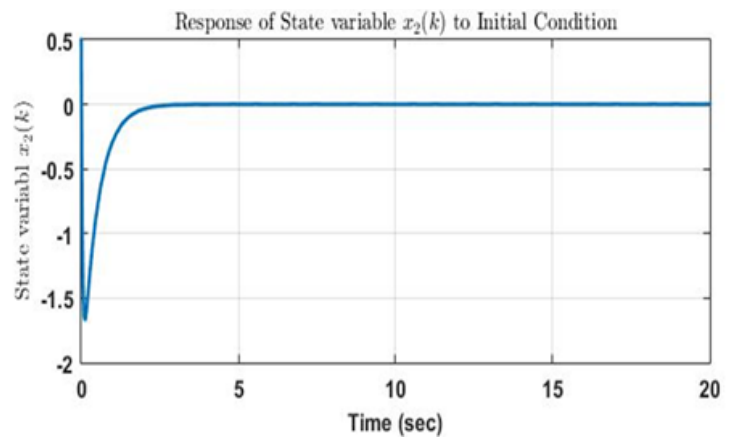

Figure 5. Showing state X2 without any disturbance

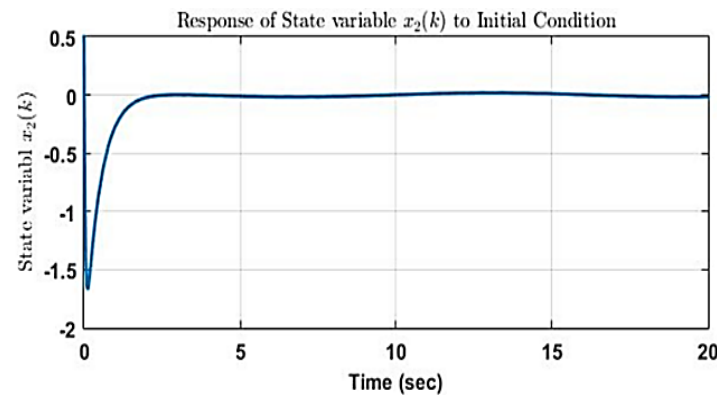

Figure 7. Showing state X2 with the disturbance 


\section{CONCLUSION}

An analysis was proposed to evaluate the stability and performance of speed control in DC motor. State-feedback control technique was used with and without disturbance. The proposed control offered higher stability and performance in the response of the system in both cased. Therefore, this technique can be used to tackle the stability issue of speed control in DC motor.

\section{REFERENCES}

[1] S. Tiwari, A. Bhatt, A. C. Unni, J. G. Singh, and W. Ongsakul, "Control of DC motor using genetic algorithm based PID controller," ICUE 2018 on Green Energy for Sustainable Development Thavorn Palm Beach Resort Karon, Phuket, Oct. 2018, doi: 10.23919/ICUE-GESD.2018.8635662.

[2] D. Pal, "Modeling, analysis and design of a DC motor based on state space approach," International Journal of Engineering Research \& Technology (IJERT), vol. 5, no. 2, Feb. 2016, doi: 10.17577/IJERTV5IS020332.

[3] P. Khanke, and S. Jain, "Speed control of Separately Excited DC Motor using various Conventional Controllers", Int. Journal of Engineering Research and Applications, vol. 5, issue 4, pp. 67-72, (Part -3), April 2015.

[4] I. G. A. P. R. Agung, S. N. Huda, and I. W. A. Wijaya, "Speed control for DC motor with pulse width modulation (PWM) method using infrared remote control based on ATmega16 microcontroller," IEEE, 2014, doi: 10.1109/ICSGTEIS.2014.7038740.

[5] A. Rinc'on, F. Angulo, and F. Hoyos, "Controlling a DC Motor through Lypaunov-like Functions and SAB Technique," International Journal of Electrical and Computer Engineering (IJECE), vol. 8, no. 4, pp. 2180-2198, Aug. 2018, doi: 10.11591/ijece.v8i4.pp2180-2198.

[6] T. Nguyen, "The control structure for DC motor based on the flatness control," International Journal of Power Electronics and Drive System (IJPEDS), vol. 8, no. 4, pp. 1814-1821, 2017, doi: 10.11591/ijpeds.v8.i4.pp18141821.

[7] C. Bharatiraja, J. Munda, I. Vaghasia, R. Valiveti, and P. Manasa. "Low cost real time centralized speed control of DC motor using lab view -NI USB 6008," International Journal of Power Electronics and Drive System (IJPEDS), vol. 7, no. 3, pp. 656-664, Sept. 2016, doi: 10.11591/ijpeds.v7i3.10478.

[8] D. Altun, "Performance comparison of fuzzy logic and PID controller for speed control of DC motor in distribution grid," International Research Journal of Engineering and Technology (IRJET), vol. 6, no. 2, Feb. 2019, doi: 10.12962/j25796216.v4.i2.151.

[9] A. Ray and F. Shabbiruddin, "Speed control techniques using fuzzy logic and response surface methodology," International Journal of Advances in Soft Computing and its Applications, vol. 4, no. 2, Jul. 2012.

[10] U. K. Bansal and R. Nartey, "Speed control of DC motor using fuzzy PID controller," Advance in Electronic and Electric Engineering, vol. 3, no. 9, pp. 1209-1220, 2013

[11] A. A. M. Zahir, S. S. N. Alhady, W. A. F. W. Othman, A. A. A. Wahab, M. F. Ahmad, "Objective functions modification of GA optimized PID controller for brushed DC motor," International Journal of Electrical and Computer Engineering (IJECE), vol. 10, no. 3, pp. 2426-2433, Jun. 2020, doi: 10.11591/ijece.v10i3.pp2426-2433.

[12] W. Yan, et al., "The PWM speed regulation of DC motor based on intelligent control," Systems Engineering Procedia, vol. 3, pp. 259-267. 2012, doi: 10.1016/j.sepro.2011.11.028.

[13] V. Sankardoss and P. Geethanjali, "Parameter estimation and speed control of a PMDC motor used in wheelchair," Energy Procedia, vol. 117, pp. 345-352, Jun. 2017, doi: 10.1016/j.egypro.2017.05.142.

[14] S. K. Das, N. Mondol and N. A. Sultana, "Design and implement of a state feedback position output controller for a Maxon S-DC motor with dSPACE," International Conference on Mechanical Engineering 2011 (ICME2011), Dhaka, Dec. 2011.

[15] I. Holič, and A. Ilka, "Robust state feedback controller design for DC-motor system," 10th IFAC Symposium Advances in Control Education, the International Federation of Automatic Control, Sheffield, UK, Aug. 2013, doi: 10.3182/20130828-3-UK-2039.00031.

[16] T. Rajesh, S. Arun jayakar, M. Kalimuthu, and G. M. Tamilselvan, "Robust Controller Design for Fixed field-DC Motor Speed Control," International Journal of Recent Technology and Engineering (IJRTE), vol. 7, no. 4S, Nov. 2018

[17] Wisam Najm Al-Din Abed, "Design of state feedback controller based bacterial foraging optimization technique for speed control of DC motor," Diyala Journal of Engineering Sciences, vol. 8, no. 1, pp. 134-152, Mar. 2015, doi: 10.24237/djes.2015.08110.

[18] N. S. Beniwal and R. Beniwal, "Automatic control systems with Matlab programming," Laxmi Publications Pvt. Ltd., 2010.

[19] M. S. Ramli, M. F. Rahmat, and M. S. Najib, "Design and modeling of integral control state-feedback controller for implementation on servomotor control," 6th WSEAS International Conference on Circuits, Systems, Electronics, Control \& Signal Processing, 2007, doi: 10.11591/ijece.v10i5.pp4782-4788.

[20] O. W. Abdulwahhab, "Design of an adaptive state feedback controller for a magnetic levitation system," International Journal of Electrical and Computer Engineering (IJECE), vol. 10, no. 5, pp. 4782-4788, Oct. 2020, doi: 10.11591/ijece.v10i5.pp4782-4788.

[21] K. A. K. Ossman, "Teaching state variable feedback to technology students using MATLAB and SIMULINK," Proceedings of the 2002 American Society for Engineering Education Annual Conference \& Exposition, Copyright, 2002, doi: 10.18260/1-2-11014. 
[22] A. Uthman, and S. Sudin, "Antenna azimuth position control system using PID controller \& state-feedback controller approach," International Journal of Electrical and Computer Engineering (IJECE), vol. 8, no. 3, pp. 1539-1550, Jun. 2018, doi: 10.11591/ijece.v8i3.pp1539-1550.

[23] T. Ashish, "Modern control design with Matlab and simulink," Indian Institute of Technology, Kanpur, India, John Wiley \& Son, 2002.

[24] P. N. Paraskevopoulos, "Modern Control Engineering", Marcel Dekker, Inc., 2002.

[25] M. B. B. Sharifian, R. Rahnavard and H. Delavari, "Velocity control of DC motor based intelligent methods and optimal integral state feedback controller," International Journal of Computer Theory and Engineering, vol. 1, no.1, Apr. 2009, doi: 10.7763/IJCTE.2009.V1.13.

\section{BIOGRAPHIES OF AUTHORS}

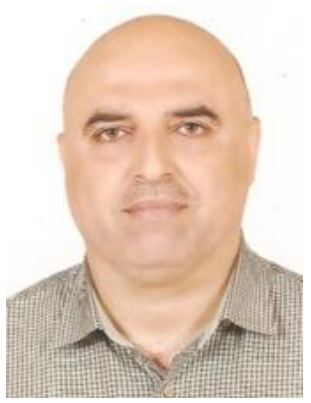

Dr. Eng. Saad Abdulmajeed Salman was born in Diyala, Iraq. He received the B.Sc. Degree in electrical and electronic engineering, master degree in electrical and electronic engineering, and $\mathrm{Ph}$. Degree in electrical and electronic Engineering form University of Technology, AlRashied College of engineering \& science, Baghdad, Iraq, in 1992, 1997, and 2006, respectively. He was working as the head of the computer engineering department in college of engineering-Diyala university-Iraq from 2004 to 2012. His current research interests include Control Systems and applications. He has worked in various colleges, including: from 1992 to 2004, working as lecturer in university of technology, Al-Rashied college of engineering \& science, Baghdad, Iraq. From 1997 to 2000 working as external lecturer in technical institute of Baquba, electrical department. From 1999 to 2004 working as external lecturer in Diyala University, college of engineering, electronic department. From 2004 to 2020 working as Lecturer in Diyala university, college of engineering, computer engineering department.

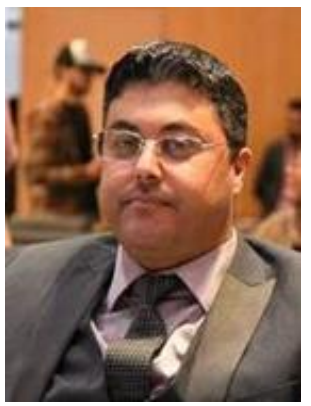

Dr.Eng. Zeyad Assi Obaid was born in Diyala, Iraq. He received his B.Sc. Degree in Control and Systems Engineering from the University of Technology, Baghdad, Iraq, in 2006. MSc in Control and Automation from University Putra Malaysia, $\mathrm{PhD}$ in Electrical Engineering from Cardiff University, UK in 2018, He has many publications in Conference proceedings and journals. His current interest includes Smart Grid, Microgrid control and operation.

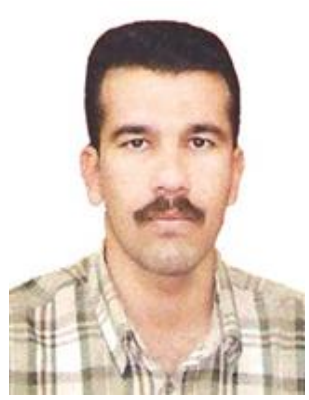

M.Sc. Hayder Salim Hameed received his B.Sc. from University of Diyala-Iraq in 2002, High Diploma in computer science from Iraqi Commission for Computers and Informatics (ICCI) in 2004, M.Sc. from University of Baghdad in 2014. He is currently Assist Lecturer in the Department of Electrical Power Engineering, College of Engineering University of Diyala Iraq. Professional Strength and Skills: His current research interests are, Power system Stability, Electrical machine Drives, Power Electronics. He has experience in practice of Electrical engineering in different fields such as electrical machines drive controller using field-programmable gate array (FPGA). He has teaching several basic subjects of the Electrical Engineering-University of Diyala-Iraq. 